ISSN 1991- 8690

Website: http://jsci.utq.edu.iq
الترقيم الدولي 8690 - 1991

Email: utjsci@utq.edu.iq

\title{
Isolation and Identification of two bioactive compounds from basidiomycetes fungus Coprinus sp.
}

Kawther T. Khalaf

\author{
College Of Pharmacy . Clinical And Laboratory Science Dept.. Basra University \\ Email : emad_yousif2000@yahoo.com
}

\begin{abstract}
$\underline{\text { Abstract }}$
The fungus Coprinus sp. was isolated and cultivation in laboratory on two PDA medium with some growth induction .Two bioactive chemical compounds were isolated and purified from mycelial culture of Coprinus sp. by using potato dextrose agar and potato dextrose broth. The two compounds were identified by using GC-mass technique .The molecular weight of purified compounds 1 and 2 were $352 \mathrm{KD}$ and $388 \mathrm{KD}$ respectively and chemical formula of compound 1 is $\mathrm{C} 21 \mathrm{H} 24 \mathrm{~N} 2 \mathrm{O} 3$ which isolated from solid medium while compound 2 is $\mathrm{C} 24 \mathrm{H} 26 \mathrm{O} 4$ which isolated from broth medium. The antibacterial activity of the purified compounds against three bacterial species E. coli, Proteus sp. and $S$. aureus were tested by using a disk diffusion agar method reaching to $40,30,20$ for compound 1 and $37,25,17$ $\mathrm{mm}$ for compound 2.
\end{abstract}

Key wards: Isolation, Identificaton, Bioactive comp., Coprinus sp.

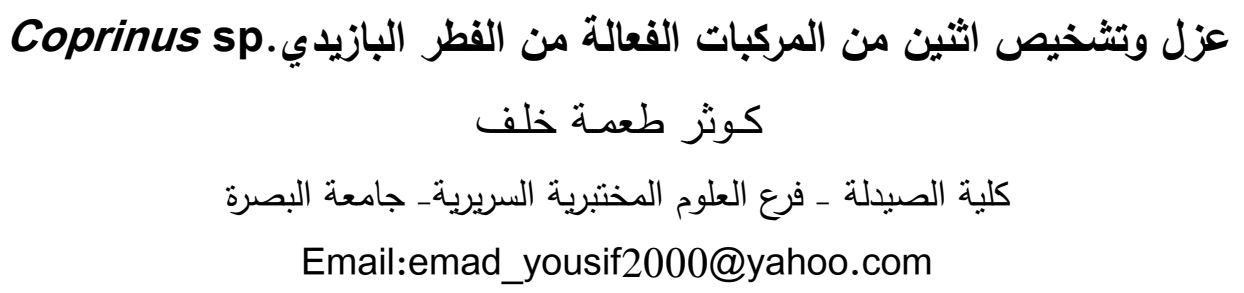

$\underline{\text { الخلاصة }}$

عزل الفطر البازيدي Coprinus sp وزرع مختبريا على وسط PDA ياستخدام محفزات نمو تم عزل وتتقية اثثين من المركبات الكيميائية

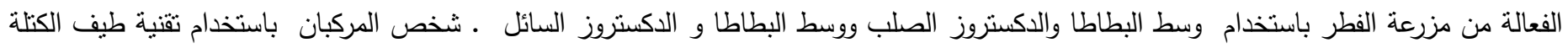

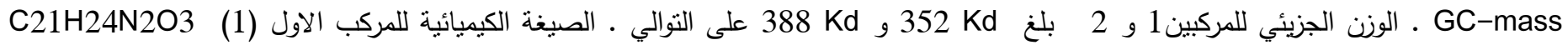
والمعزول من الوسط الصلب بينما الصيغة الكيميائية للمركب الثاني (2) C24H26O4 والمعزول من الوسط السائل ـ أختبرت الفعالية الحيوية للمركبين ضد بعض الانواع البكتيرية Proteus sp. و E. coli.، S. aureus باستخدام طريقة الأقراص والبالغة 40 ، 30 و 20 مليمنز للمركب الاول و 37 و 30

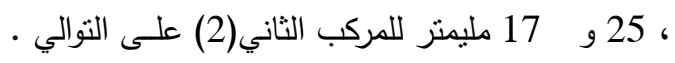
كلمات المفتاح : عزل،تشخيص ، مركبات فعالة ، الفطر البازيدي.

\section{Introduction}

The researches interest to explore new antimicrobial agents from fungi is continued ,fungi are a rich source of bioactive secondary metabolites and mushroom -forming fungi are especially known for the synthesis of numerous bioactive compounds (Anke et al., 2004 ; Keller et al., 2005 ; Agger , 2009 ; Muhsin et al., 2011 ).
Coprinus belongs to mushrooms, which is a black spored family coprinaceae ( all species go through an auto digestion at maturity in which the cap forms black spores ).The genus Coprinus is considered to be more than 100 species distributed from the northern hemisphere to south African ( Keirle et al ., 2004 ). The classification of the Coprinus species is still unclear because it was only based on morphological 
characteristics without molecular analysis ( Mwita et al., 2010 ).Extracts from several members of the genus Coprinus are known in many part of the world to exhibit among others, antimicrobial , antitumor , hypoglycemic, antinematodes and antioxidant effects . ( Ndyetabura et al., 2010 ).Examples of the bioactive compounds that have been reported present in Coprinus mushrooms extracts are : abroad spectrum bioactive indole compound tryptamine ( Worthen et al., 1962 ), Miaceol ( Asterol ) with antibacterial activity against the bacteria Corynebacterium xerosia and Staphylococcus aureus ( Zahid et al., 2006 ) and (2,2)4-oxo-2,5- heptadienedioic acid, which has inhibitory activity against glutathione S- transferase an enzyme that have been implicated in the resistance of cancer cells against chemotherapeutic agents especially alkylating drugs ( Zahid et al., 2006 ).According to our knowledge so far a little information is available about the production of secondary bioactive metabolites by this fungus, this report elucidates interesting chemical compound, extracted, purified and identified from mycelial culture of Coprinus sp. As a bioactive agents tested against a selected species of bacteria .

\section{Material and Methods}

\section{1: Fungal Mushroom culture}

Fruiting bodies were collected from palm trees ( Phoenix dactylifera ) southern of Iraq . In the laboratory, small Pieces ( $0.5 \mathrm{~cm}$ long ) were cut from the fruiting body surface, sterilized with $10 \%$ sodium hypochlorate for $3 \mathrm{~min}$., washed with sterile distilled water and placed on potato dextrose agar (PDA) with growth indicated (Aspargine and thiamine ) in petri dishes, plates were incubated at $25 \pm 1$ Co for two weeks . After cultivation, the mycelium was removed from the agar medium surface and amended into a liquid culture medium potato dextrose broth (PDB) in $1 \mathrm{~L}$ conical flasks and incubated at $25 \mathrm{Co}$ in a rotary shaker incubator for 3 weeks .

\section{2: Extraction, Isolation and Purification}

The fungal culture in broth medium was filtered on Watmann No. 1 filter paper, the filtrate was extracted three time with ethyl acetate $(1: 1 \mathrm{v} / \mathrm{v})$ using separating funnel, while fungal culture on the solid media prior to extraction with ethylacetate,the solid medium were diluted with $\mathrm{H} 2 \mathrm{O}$ and blended using blender ( Zur , 2001 ).Organic layer was collected and dehydrated with $\mathrm{Na} 2 \mathrm{SO} 4$ then placed in Petri dishes and dried at room temperature, thin layer chromatography ( TLC) was applied for the isolation of extracted metabolites using silica gel of $2 \times 10 \mathrm{~cm}$ (Silica gel
GF2 Merck ) and Rf value ( Rate flow ) were measured . Purification of extracted compounds was made on silica gel column chromatography ( silica gel mesh 60 ) ( Column $1.5 \times 50 \mathrm{~cm}$ and elution with methanol - ethyl acetate (1:1). a further purification of fraction compound were made by using another column $1.5 \times 50 \mathrm{~cm}$ and using eluent cyclohexane and ethyl acetate (1: 1 ). The identification of the purified compounds was made by using Gas chromatography GC-Mass technique type (Simadzu . GCMS-QP2010 Ultra )

\section{3: Bioactive test}

Disc diffusion agar method ( Casals , 1979 ) was used to examine the antimicrobial activity of the purified compounds, Three strains of pathogenic bacteria from ( Lab. of Pharmacy college ) , Escherichia coli, Proteus sp. and Staphylococcus aureus were used for this purpose . $2.5 \mathrm{mg}$ of the dried fungal extract was dissolved in $1 \mathrm{ml}$ of dimethyl sulfuoxide (DMSO) solvent used as stock solution for this test. Disk of $0.6 \mathrm{~mm}$ diameter Whatmann No. 1 filter paper was sterilized and soaked in the fungal extract solution and placed on plates containing Muller-Hinton agar ( MHA) medium inoculated with $0.1 \mathrm{ml}$ suspension of bacterial strains by streaking method. The test was carried out in triplicates. Antimicrobial activity was assayed by measuring the inhibition zone around the disk in $\mathrm{mm}$.

\section{Results :}

The fungus Coprinus sp. Which isolated in this study has some characters such as : Basidiocarp brown in color, brown cap with brown -black spores ( 4.5 $5.5 \times 4-7.5) \mu \mathrm{m}$ stalk diameters $(5 \times 0.25) \mathrm{cm}$ and spores are brown in color. Mycelium white in color when grow on the solid media and grow up on the media surface. Two compounds were isolated and purified from solid and broth culture of Coprinus sp. Mycelium. The compound (1) isolated from solid culture , while compound (2) isolated from broth culture . Based on Gas chromatography (GC-mass) apparently that the molecular formula of compound (1) is $\mathrm{C}_{21} \mathrm{H}_{24} \mathrm{~N}_{2} \mathrm{O}_{3}$ with molecular weight $352 \mathrm{Kd}$ and its chemical name is 2-(1-hydroxymethyl - propenyl ) 1,2,6,7,12,12b-hexahydro-indo [2,3-a ] quinolizine -3carboxylic methyl ester showed in fig (1), While the molecular formula of compound (2) is $\mathrm{C}_{24} \mathrm{H}_{36} \mathrm{O}_{4}$ and its name is Cycloheptylnonphthallate with molecular weight $388 \mathrm{Kd}$ fig ( 2 ). The purified compound 1 and 2 appeared antibacterial activity against bacterial species . The inhibition zone diameter of compound (1) reach to 
( 40, 30, 20 ) $\mathrm{mm}$ for S. aureus, E. coli and Proteus sp. respectively and $(37,25,17) \mathrm{mm}$ of compound (2) for three bacterial species respectively fig (3) .

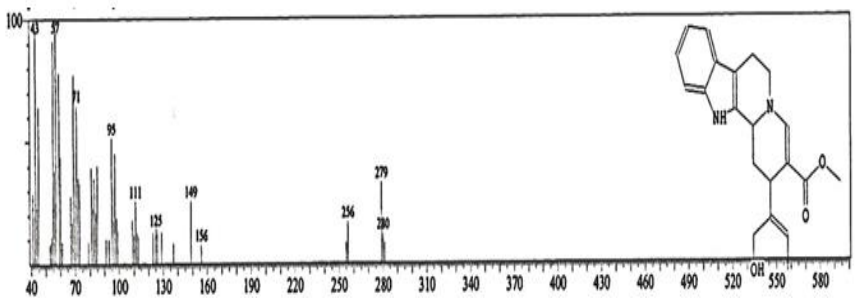

Fig(1): Chemical structure and GC -Mass spectroscopy of compound -1 (2-(1-hydroxymethyl-propenyl)-

$1,2,6,7,12,12 b$-hexahydro-indo [ 2,3-a ] quinolizine -3carboxylic methyl esteIsolation from solid media

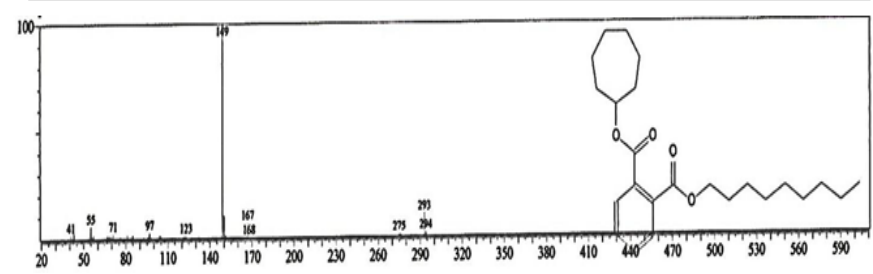

Fig (2): Chemical structure and GC-Mass spectroscopy of compound- 2(Cycloheptylnonphthalate) isolation from broth media
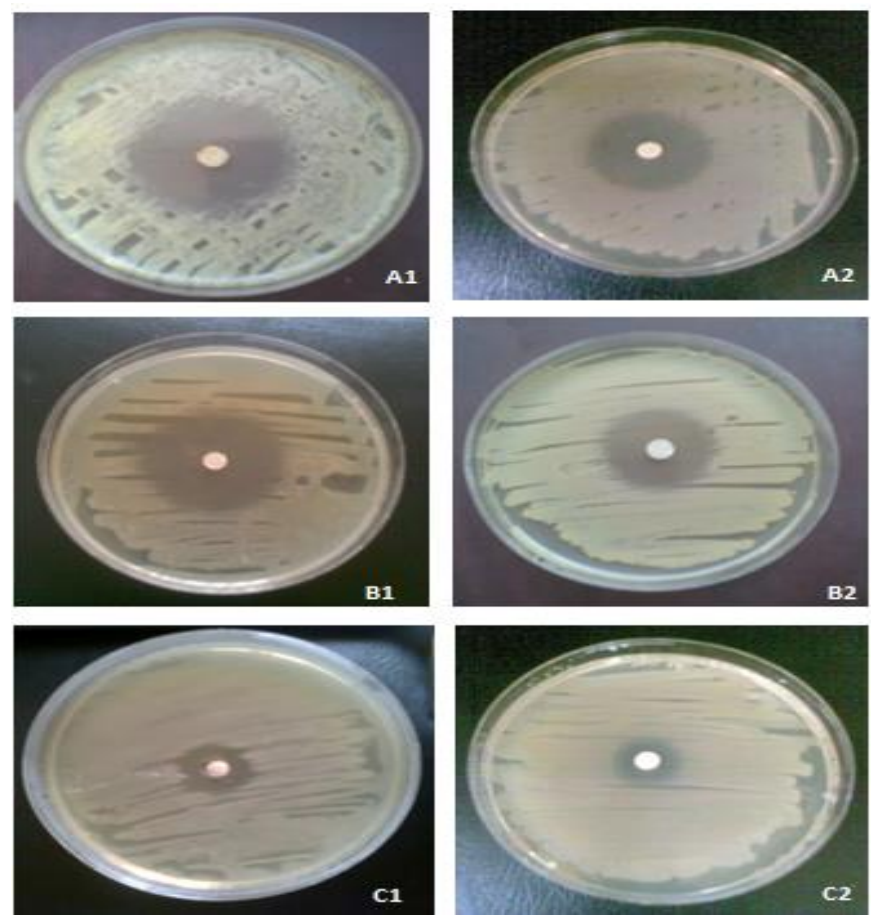

Fig (3): Inhibition zone diameter (mm) :- 1: compound No. (1) and 2: Compound $\mathrm{No}(2)$
$\mathrm{A}=$ E. coli
$\mathrm{B}=S$. aureus
$\mathrm{C}=$ Proteus sp.

\section{Discussion}

Fungi in general and mushroom in particular are a good source for antimicrobial products ( Janes et al., 2007 ). Results showed the activity of two compounds purified from Coprinus sp. $(1,2)$ against gram positive and gram negative bacteria, so this activity may be due to active substances present in the Coprinus sp. tissues ( Ndyetabura et al., 2010 ), also these results agreed with Zenkora et al., ( 2003 ) whom reported that the Coprinus representatives produces compounds which are able to inhibit growth of all common gram-negative and gram positive bacteria and fungal strains .The antimicrobial activity of compound (1)against bacterial strains may be due to the quinolizine and indole group in its structure, also this groups have different biological activity such as antimicrobial, antiinflamatory, antituberculosis, cytotoxicity ( Thakur et al., 2010 ), while the antimicrobial activity of compound (2) may be due to its one of the phthalide derivatives which are compounds of polyketide metabolism, they are produced by a wide range of organisms, i.e marine and terrestrial fungi ( Almedia et al., 2011 ) . Phthalides exhibit equaly broad spectrum of bioactivity, including modulation of central nervous system protection against brain eschemia, as well as antibacterial , antifungal and phtytoxic activity. Moreover, the rings compounds acts as a protoplasm toxin to destroy the cell wall system and to precipitate protein in cells (Gayon , 1972).The compound produced from solid media have more biological activity against bactetria than liquid media, several researches showed that produced through solid media are more stable and produced in higher quantities than liquid. In this fermentation technique, the substrate can be used for long fermentation periods , hence, this technique supports controlled release of nutrients ( Subramaniyam and Vimala , 2013 ). The role of the physiological and genetic properties of the microorganism used during growth on solid substrates compared with aqueous solution has so for been all but neglected ,despite the fact that it may be the microbiology that makes solid state fermentation advantageous against submergied fermentation biotechnology ( Acura-Arguelus et al., 2004 ).The fact basidiomycetes have been insufficiently investigated coupled with broad range of structural types of antibiotics. However basidiomycetes may become source of new and useful bioactive compound ( Srivastava and Sharma, 2011). To our knowledge, no investigation has been performed for comparing 
antimicrobial activity potential of basidiomycetes strains . Further studies on isolation and identification of the active compounds may provide a better source for developing new therapeutic agents .

\section{References}

Acuna,A. ; Holker, U. ; Hofer, M. and Lenz, J. (2004).Biotechnological advantages of laboratory -scale solid state fermentation with fungi . J.of Applied Microbiology and Biotechnology Vol. (64) : 175-186 .

Agger, S. ; Fernando , L. G. and Claudia , S.D. ( 2009) - Diversity of sesquiterpene synthesis in the basidiomycete Coprinus cinereus . Molecular Microbiol , 72(5): 1181-1195.

Almedia , G. ; kehraus , S. ; Pyudencio , M. and Konig , G. M. ( 2011) . Marilones A.C , Pthalides from the spong-derived fungus Stachylidiumsp . Beilstein J. of Organic Chemistry , 7: 1636-1642 .

Anke, T.; Werle, A. ; Kappe , R. and Stemer , D. ( 2004) .Laschiatrion a new antifungal agent from a Favolaschia species (basidiomycetes ) active against human pathogen . J. Antibiot. 57:496-501 .

Casals , J.B. ( 1979) . Tablet sensitivity of pathogenic fungi , J. of Clin. Pathol. 32 : 719-722 .

Gayon , P.R.( 1972). Plant phenols . $7^{\text {th }}$ ed. Oliver Boyed Edinbury ., pp. 254 .

Janes , D; Kreft , S. ; Jure , M. ; Seme , K. and Strukelj , B. (2007). Antibacterial activity in higher fungi : Mushrooms and endophytic fungi from solnenia . Pharma Biol. 45:700-706 .

Keirle , M.R. ; Hemmes , D.E. ; Desjardin , D.E.(2004). Agaricales of the Hawaiian Islands . Agaricaceae : Coprinus and Podaxix ; Psathrellaceae : Coprinopsis , Coprinellus and Parasola ) Fungal diversity $15: 33-124$.

Keller , N. P. ; Turner, G. and Bennett , J.W. ( 2005). Fungal secondary metabolism - from biotechemistry to genomics . Nat Rev. Microbial 3:937-947 .

Muhsin , T.M. ; AL- Duboon , A.A. and Khalaf , K.T. ( 2011). Bioactive compounds from a polypore fungus Ganoderma applanatum ( Pers .ex Wallr.) Pat. JJBS , 4:205-212.

Mwita , L.N. ; Mashandete , A.M. and Lyantagaye S.L. ( 2010 ). Improved antimicrobial activity of the Tanzanian edible mushroom Coprinus cinereus ( Schaeff) Gray be chicken manure supplemented solid sisal wastes substances. J. of Yeast and Fungal Research (10):201-206 .
Ndyetabura , T. ; Lyantagaye , S.L. and Ashandete , A.M. ( 2010). Antimicrobial activity of ethylacetate extracts from edible Tanzanian Coprinus cinerew ( Schaeff) S. Gray S. Lat . cultivated on grasses supplemented with cow dung manure . J. of Agriculture and Biological Science, Vol. (5) : 79-85 .

Srivastava , M.P. and Sharma, N.(2011). Antimicrobial activities of basidiocarp of some basidiomycetes strains against bacteria and fungi . J. Mycol. Plant. Pathol:Vol.41(2): 332-334.

Subramaniyam , R. and Vimala , R. ( 2010) . Solid state and submerged fermentation for the production of bioactive substancses : Acomparative study . International J. of Science and nature . Vol. 3(3) : 480-486 .

Thakur , A.S. ; Jha, A.K.,Vermo , P. ; Deshmuk , R. Devangan, D. and Chandy, A. ( 2010 ). Synthesis and evaluation of some vewquinolone and pyrido $(2,3, \mathrm{~b})$ indole derivatives . IJCP ( International Journal of comprehensive pharmacy ). 3(13): 104 .

Worthen , L.R. stessel , G. J. and Youngken , H. W. ( 1962). The occurrence of indole compounds in Coprinus species . J. of Economic Botany, 16(4) : 315-318 .

Zahid ,S. ; Udenigwe , C.C. ; Ata , A. ; Eze , M.O. ; Segstro , E.P. and Holloway, P. ( 2006 ). New bioactive natural products from Coprinus micaceus. J. of Natural Product Research . 20(14): 1283-1289.

Zenkova , V.A. ; Frememkova , E. Ershova , E.Y. and Dudnik , Y.V. (2003). Antimicrobial activity of medicinal mushrooms from the genus Coprinus (Fr.) S.F. Gray ( Agaricomycetideae ) Int. J. Med . Mushroonms . Begell, Digital Library 5(1).

Zur, E. (2001). Isolation, Structure determination and biological activity assessment of secondary metabolites from marine -derived fungi .Ph.D . thesis .Von cludia Osterhage . 186 pp. 